\title{
Copper Pine of Calves
}

\author{
BY S. JAMIESON \\ Veterinary Laboratory, North of Scotland College of Agriculture, \\ Mill of Craibstone, Bucksburn, Aberdeenshire \\ AND RUTH ALLCROF'T \\ Veterinary Laboratory, Ministry of Agriculture, Weybridge, Surrey
}

(Received 28 October I949)

Unthriftiness in grazing calves has been recognized by farmers in parts of Caithness during the last 10 years. A noticeable feature of the disorder is that Aberdeen-Angus and cross-bred West Highland calves are chiefly affected. Adult cattle of these breeds grazing the same pastures do not appear to be clinically affected.

In Caithness, cattle are housed from November to April and managed so that calves are born in March and April. Cows and calves are then turned out to pasture where they remain until October, when the calves are sold.

The geological formation of Caithness is Middle Old Red Sandstone extensively overlaid with peat, but around coastal areas sandy machairs are common. About $70 \%$ of the county is classed as moor and heathland. Of the remaining land about $15 \%$ is arable and $5 \%$ permanent pasture, mostly reclaimed from peat, but a considerable proportion of this is still marginal.

Although the disorder has been attributed to various factors, one of which was excess molybdenum in the pastures, no observations have been made to ascertain the true cause. In 1945, one of us (S. J.) made the empirical observation that the disorder could be cured by administration of small amounts of copper sulphate, but detailed investigations were not commenced until June 1948, when the present observations were made.

\section{Clinical description of the disease}

Initial symptoms may appear about a month after calves are put out on pasture. The first sign of the condition is a stilted gait, particularly of the hind limbs. This is followed by a slowly progressive loss of condition during the next 4 or 5 months, which in severe cases results in extreme emaciation and death. In black-coloured breeds the hair around the eyes becomes grey, giving the animal a 'spectacled' appearance. This depigmentation frequently extends down the forehead and lower jaw, and in severely affected animals a general greying of the hair takes place, usually along the back and forelegs. In brown-coloured breeds, the coat changes to a muddy yellow. Pl. I, I shows the appearance of a typical 'pining' calf.

Diarrhoea is not a common symptom but has been observed in a few instances. No pica has been noted even in badly affected animals.

The incidence of clinical cases is usually $20-25 \%$ of grazing calves, but the rate varies on different farms and may reach $100 \%$. 'There is a year-to-year variation in 
incidence and severity of the disorder, and in certain seasons the condition may be so severe that a number of calves die at $4^{-6}$ months of age. Calves that are clinically affected, but survive, rapidly improve under winter-feeding conditions, the depigmented areas on the coat disappear and the growth rate increases. These calves are, however, easily recognized the following year, as their development remains suboptimal even though the clinical condition does not recur when they are depastured during their 2nd year.

On farms where the condition is prevalent, there is sometimes a history of infertility and suppression of oestrus in adult cattle, and sporadic outbreaks of swayback in lambs are common.

\section{EXPERIMENTAL}

\section{Preliminary investigations}

Plan of experiments

Four farms, B, D, O and S, were selected for their high incidence of the disorder, and blood samples were taken from calves, cows and sheep to gain preliminary information which might indicate the aetiology of the condition. Copper, haemoglobin, molybdenum, inorganic phosphorus, calcium and magnesium were determined on these samples.

\section{Study of pastures}

Samples were collected for copper and molybdenum estimations from various fields on the four farms during July and October. Seven samples were taken from each of farms $\mathrm{D}$ and $\mathrm{O}$, two from $\mathrm{B}$ and one from $\mathrm{S}$.

\section{Experiments with copper-sulphate therapy}

Since one of us (S. J.) had made the empirical observation that small doses (about 2 g.) of copper sulphate given once would cure and prevent the disorder, it was decided to examine the effect of a single small dose of copper sulphate (Exp. I) and of repeated larger doses (Exp. 2).

Exp. I. Study of single small doses. On farm D nine 3-month-old calves with their mothers, all in fair condition, were divided at random into three equal groups and put on to fields 8 and 9 (see Table 2).

The calves in group 1, nos. 2, 3 and 4 , received no therapeutic treatment and served as controls. Those in group 2, nos. 5, 6 and 9, were given one intravenous injection of $50 \mathrm{mg}$. copper as A.R. copper sulphate in normal saline. Group 3, calves nos. 1,7 and 8 , was given one dose of $500 \mathrm{mg}$. copper as A.R. copper sulphate by mouth.

This treatment was carried out in June 1948. The calves were allowed to run with their mothers according to the usual practice but were confined to fields 8 and 9 (see Table 2). Blood samples were taken from calves and cows before treatment and subsequently at monthly intervals for 4 months. Levels of copper, haemoglobin, inorganic phosphorus and molybdenum were determined. Samples of faeces were collected at the same time for worm-egg counts.

Exp. 2. Study of repeated larger doses. On farm $\mathrm{O}$ eight cows with their calves were 
divided at random into two equal groups $A$ and $B$ and put on fields Io and II (see Table 2).

Group A consisted of cows $1,2,3$ and 5 with their calves numbered correspondingly. In group B cows and calves, nos. 4, 6, 7 and 8 , were given 5 g. A.R. copper sulphate by mouth in gelatine capsules at monthly intervals for 3 months. Blood samples were taken before treatment, and subsequently at monthly intervals, for analyses similar to those in Exp. I. Faecal samples were similarly examined.

Collection of tissues for analysis. Both experiments terminated in October 1948, when calves 2, 3 and 6 from farm $D$ in Exp. I and calves 3, 5 and 8 from farm $O$ in Exp. 2, as well as one typical pining calf from farm $\mathrm{S}$, were slaughtered. Liver, spleen, heart and kidney tissues were taken for copper and molybdenum estimation and for histological examination.

\section{Observations on distribution and incidence of the disorder}

Since the condition was recognized clinically in widely scattered areas of Caithness, a survey of blood-and liver-copper values was made.

Blood-copper survey. Blood samples were taken from 222 cows and 509 calves and stirks distributed on 123 farms chosen at random. Samples were taken from apparently healthy animals as well as from pining calves.

Liver-copper survey. Forty-five random samples of liver from adult cattle native to Caithness were collected from the slaughter-houses in the area. For comparison forty-two liver samples were obtained at random from slaughter-houses in Aberdeenshire.

\section{Methods}

Chemical. Copper was estimated by the method of Eden \& Green (1940); molybdenum by the method of Perrin (1946); haemoglobin by the acid-haematin method of Newcomer (1923), and inorganic phosphorus by the method of Fiske \& Subbarow (1925). Calcium and magnesium were determined on the same sample of serum using the modification of Clark \& Collip (1925) of the method of Kramer \& Tisdall (1921) for calcium, and the method of Denis (1922) for magnesium.

Pathological. Portions of liver, spleen, heart, kidney, cerebrum, cerebellum and spinal cord from all the slaughtered animals were examined. Tissues for examination were collected immediately after slaughter and fixed in $10 \%$ neutral formol-saline. All tissues were examined from paraffin-embedded sections stained by haematoxylin and eosin. Paraffin-embedded sections of liver, spleen, kidney and heart were stained by the method of Gomori (Clayden, 1948) to demonstrate haemosiderin. Formol-fixed liver, heart and kidney were cut on the freezing microtome and stained by Scharlach R for the demonstration of fat. All haematological examinations were duplicated, and the methods used were those recommended for bovine species by Holman (1944). The colour: count ratio (C.C.R.) and the colour: volume ratio (C.v.R.) were estimated by the formulas described by Bennetts, Beck, Harley \& Evans (I94I). The method used for the histological demonstration of glycogen was that described by Vallance-Owen (1948).

The worm-egg count of the faeces samples was estimated by the method of Gordon \& Whitlock (1939). 
RESULTS

\section{Preliminary investigations}

Analytical data for blood samples from animals on the four farms B, D, O and $S$ are given in Table I. It is evident from this preliminary survey that all the blood-copper values were below the generally accepted normal range of $0.07-0.17 \mathrm{mg} / 100 \mathrm{ml}$.

Values for molybdenum, haemoglobin, inorganic phosphorus and calcium were all within normal ranges. Magnesium values for the cows on farm $D$ were normal, but the values for the calves were at the lower end of the commonly accepted normal range of I. $8-3.2 \mathrm{mg} / 100 \mathrm{ml}$. serum. Subsequent estimations showed that the magnesium values increased during the experimental period. It is of passing interest to note that one of the cows on farm $\mathrm{D}$ developed a typical hypomagnesaemic syndrome at the end of the experimental period, with a serum value of $\mathrm{I} \cdot \mathrm{I} \mathrm{mg} . / \mathrm{roO} \mathrm{ml}$. and died before effective treatment could be given.

Table I. Mean values for blood copper, molybdenum, haemoglobin and inorganic phosphorus and for serum calcium and magnesium of animals on four farms where 'pining' occurs in calves

\begin{tabular}{|c|c|c|c|c|c|c|c|c|}
\hline Farm & $\begin{array}{l}\text { Type } \\
\text { of } \\
\text { animal }\end{array}$ & $\begin{array}{c}\text { No. } \\
\text { of } \\
\text { samples }\end{array}$ & $\begin{array}{c}\text { Copper } \\
\text { (mg./ } \\
\text { 100 ml.) }\end{array}$ & $\begin{array}{l}\text { Molyb- } \\
\text { denum } \\
\text { (mg.il.) }\end{array}$ & $\begin{array}{l}\text { Haemo- } \\
\text { globin } \\
(\mathrm{g} . / \\
100 \mathrm{ml} .)\end{array}$ & $\begin{array}{c}\text { Inorganic } \\
\text { phos- } \\
\text { phorus } \\
\text { (mg./ } \\
100 \mathrm{ml} \text { ) }\end{array}$ & $\begin{array}{c}\text { Calcium } \\
\text { (mg./ } \\
\text { 100 ml. } \\
\text { serum) }\end{array}$ & $\begin{array}{c}\text { Mag- } \\
\text { nesium } \\
\text { (mg./ } \\
\text { roo ml. } \\
\text { serum) }\end{array}$ \\
\hline B & $\begin{array}{l}\text { Cow } \\
\text { Calf }\end{array}$ & $\begin{array}{l}5 \\
5\end{array}$ & $\begin{array}{l}0.03 \\
0.03\end{array}$ & $\begin{array}{l}<0.05 \\
<0.05\end{array}$ & $\begin{array}{l}12 \cdot 7 \\
13.9\end{array}$ & - & - & - \\
\hline D & $\begin{array}{l}\text { Cow } \\
\text { Calf } \\
\text { Sheep }\end{array}$ & $\begin{array}{r}6 \\
12 \\
16\end{array}$ & $\begin{array}{l}0.03 \\
0.04 \\
0.06\end{array}$ & $\begin{array}{l}<0.05 \\
<0.05 \\
<0.05\end{array}$ & $\begin{array}{r}12 \cdot 9 \\
15 \cdot 3 \\
-\end{array}$ & $\begin{array}{l}3.5 \\
5.8 \\
-\end{array}$ & $\begin{array}{l}10 \cdot 9 \\
11 \cdot 5 \\
-\end{array}$ & $\begin{array}{l}2 \cdot 7 \\
1.9 \\
-\end{array}$ \\
\hline $\mathrm{O}$ & $\begin{array}{l}\text { Cow } \\
\text { Calf }\end{array}$ & $\begin{array}{l}8 \\
8\end{array}$ & $\begin{array}{l}0.04 \\
0.05\end{array}$ & $\begin{array}{l}<0.05 \\
<0.05\end{array}$ & $\begin{array}{l}12.6 \\
14.5\end{array}$ & $\begin{array}{l}4 \cdot 7 \\
7 \cdot 7\end{array}$ & - & - \\
\hline$S$ & $\begin{array}{l}\text { Cow } \\
\text { Calf }\end{array}$ & $\begin{array}{l}2 \\
8\end{array}$ & $\begin{array}{l}0.03 \\
0.03\end{array}$ & 二 & $\begin{array}{l}12 \cdot 3 \\
12 \cdot 1\end{array}$ & - & - & - \\
\hline
\end{tabular}

\section{Study of pastures}

The results in Table 2 show that copper values for the pastures on farms B, D and $S$ are within the normal range of 7-24 P.p.m. in dry matter (D.M.) reported by Eden (1944) for parts of England and Wales. The values for fields 14 and 16 on farm $O$ are on the low side, but not as low as some of the severely deficient pastures reported in Western Australia by Beck (194I) and in New Zealand by Cunningham (1946).

The molybdenum values for some fields, especially on farm $D$, are higher than the usual I or 2 p.p.m. found in normal pastures. The values of 19.5 and 16.1 p.p.m in D.M. for fields 8 and 9 respectively on farm $D$ approach the lower end of the range found in the teart areas of Somerset (Ferguson, Lewis \& Watson, 1943), but symptoms of teartness, as manifested in Somerset, were not observed in any animals on these two fields. 
Table 2. Copper and molybdenum contents of pasture samples from four farms where 'pining' occurs in calves

\begin{tabular}{|c|c|c|c|}
\hline \multirow[b]{2}{*}{ Farm } & \multirow[b]{2}{*}{ Description of field } & \multicolumn{2}{|c|}{ Content in dry matter } \\
\hline & & $\begin{array}{l}\text { Copper } \\
\text { (p.p.m.) }\end{array}$ & $\begin{array}{l}\text { Molybdenum } \\
\text { (p.p.m.) }\end{array}$ \\
\hline B & $\begin{array}{l}\text { Field } x \text {. Second year ley } \\
\text { Field 2. Permanent pasture }\end{array}$ & $\begin{array}{l}7 \cdot 7 \\
86\end{array}$ & $\begin{array}{l}8 \cdot 4 \\
5 \cdot 0\end{array}$ \\
\hline $\mathrm{D}$ & $\begin{array}{l}\text { Field 3. Permanent pasture. No lime for many years } \\
\text { Field 4. Permanent pasture. No lime for many years } \\
\text { Field 5. Permanent pasture. No lime for many years } \\
\text { Field 6. Permanent pasture. Limed } 6 \text { years ago, } 0.5 \text { ton'acre } \\
\text { Field 7. Permanent pasture. No lime for many years } \\
\text { Field 8. Second year ley. Limed } 6 \text { years ago } \\
\text { Field 9. Permanent pasture. No lime for many years }\end{array}$ & $\begin{array}{r}14 \cdot 3 \\
12 \cdot 8 \\
8 \cdot 8 \\
20 \cdot 8 \\
17 \cdot 7 \\
9 \cdot 7 \\
9 \cdot 5\end{array}$ & $\begin{array}{r}7 \cdot 4 \\
4 \cdot 3 \\
3 \cdot 2 \\
9 \cdot 8 \\
9 \cdot 1 \\
19 \cdot 5 \\
16 \cdot 1\end{array}$ \\
\hline 0 & $\begin{array}{l}\text { Field ro. Permanent pasture. No lime for many years } \\
\text { Field 11. Permanent pasture. No lime for many years } \\
\text { Field } 12 \text {. Permanent pasture. No lime } \\
\text { Field } 13 . \text { Permanent pasture } \\
\text { Field 14. Permanent pasture } \\
\text { Field } 5 \text {. Permanent pasture } \\
\text { Field } 16 \text {. Permanent pasture }\end{array}$ & $\begin{array}{r}9 \cdot 5 \\
13 \cdot 7 \\
15 \cdot 8 \\
9 \cdot 4 \\
4.8 \\
8 \cdot 4 \\
6 \cdot 8\end{array}$ & $\begin{array}{l}4 \cdot 3 \\
3.8 \\
4 \cdot 3 \\
3 \cdot 5 \\
1 \cdot 1 \\
1 \cdot 8 \\
1 \cdot 4\end{array}$ \\
\hline$s$ & Field 17 . Permanent pasture. No lime & $13 \cdot 6$ & $7 \cdot 7$ \\
\hline
\end{tabular}

\section{Experiments with copper-sulphate therapy}

Exp. I. Study of single small doses

'Ihe effect on clinical condition and on copper values of blood and tissues of a single small dose of copper sulphate given intravenously and orally to calves on farm I) is shown in Tables 3 and 4 .

Table 3. Exp. I. Effect of a single dose of copper sulphate on blood-copper values of calves on farm $D$

\begin{tabular}{|c|c|c|c|c|c|c|c|c|}
\hline \multirow[b]{2}{*}{ Group } & \multirow[b]{2}{*}{ Treatment } & \multirow[b]{2}{*}{$\begin{array}{l}\text { Calf } \\
\text { no. }\end{array}$} & \multicolumn{5}{|c|}{ Blood-copper values (mg./100 ml.) } & \multirow[b]{2}{*}{ Clinical condition } \\
\hline & & & $\begin{array}{l}\text { Before } \\
\text { treatment }\end{array}$ & $\begin{array}{l}\text { After } \\
\text { I month }\end{array}$ & $\begin{array}{l}\text { After } \\
2 \text { months }\end{array}$ & $\begin{array}{l}\text { After } \\
3 \text { months }\end{array}$ & $\begin{array}{l}\text { After } \\
4 \text { months }\end{array}$ & \\
\hline \multirow[t]{3}{*}{ (Control) } & No copper & $\begin{array}{l}2 \\
3\end{array}$ & $\begin{array}{l}0.05 \\
0.02\end{array}$ & $\begin{array}{l}0.05 \\
0.02\end{array}$ & $\begin{array}{l}0.04 \\
0.03\end{array}$ & $\begin{array}{l}0.02 \\
0.01\end{array}$ & $\begin{array}{l}0.03 \\
0.02\end{array}$ & $\begin{array}{l}\text { Normal } \\
\text { Thin, depigmentation of } \\
\text { hair around eye }\end{array}$ \\
\hline & & 4 & 0.04 & 0.04 & - & 0.03 & 0.03 & $\begin{array}{l}\text { Thin, depigmentation of } \\
\text { hair around eye }\end{array}$ \\
\hline & & Mean & 0.037 & - & - & - & 0.027 & \\
\hline \multirow[t]{2}{*}{2} & $\begin{array}{l}\text { One dose of } 50 \mathrm{mg} \text {. } \\
\text { copper as copper- } \\
\text { sulphate solution }\end{array}$ & $\begin{array}{l}5 \\
6 \\
9\end{array}$ & $\begin{array}{l}0.04 \\
0.05 \\
0.05\end{array}$ & $\begin{array}{l}0.06 \\
0.06 \\
0.07\end{array}$ & $\begin{array}{l}0.05 \\
0.05 \\
0.05\end{array}$ & $\begin{array}{l}0.05 \\
0.05 \\
0.04\end{array}$ & $\left.\begin{array}{l}0.03 \\
0.02 \\
0.03\end{array}\right\}$ & $\begin{array}{l}\text { Good } \\
\text { No symptoms of pine }\end{array}$ \\
\hline & & Mean & 0.047 & 0.063 & - & - & 0.027 & \\
\hline \multirow[t]{2}{*}{3} & $\begin{array}{l}\text { One dose of } 500 \mathrm{mg} \text {. } \\
\text { copper as copper } \\
\text { sulphate by mouth }\end{array}$ & $\begin{array}{l}\mathbf{1} \\
7 \\
8\end{array}$ & $\begin{array}{l}0.07 \\
0.08 \\
0.09\end{array}$ & $\begin{array}{l}0.09 \\
0.06 \\
0.06\end{array}$ & $\begin{array}{l}0.06 \\
0.05 \\
0.09\end{array}$ & $\begin{array}{l}0.03 \\
0.04 \\
0.06\end{array}$ & $\left.\begin{array}{l}0.04 \\
0.03 \\
0.05\end{array}\right\}$ & $\begin{array}{l}\text { Good } \\
\text { Noo symptoms of pine }\end{array}$ \\
\hline & & Mean & 0.080 & - & - & - & 0.040 & \\
\hline
\end{tabular}

Blood. Table 3 shows that blood-copper values for the three control calves (group I) were low throughout the experimental period, and even decreased from the low preexperimental mean of 0.037 to the lower mean of $0.027 \mathrm{mg} . / 100 \mathrm{ml}$. at the end of the 4-month period. 
In group 2, which received a single intravenous injection of $50 \mathrm{mg}$. copper, there was a slight temporary increase from a mean of 0.047 to one of $0.063 \mathrm{mg} . / 100 \mathrm{ml}$. for the month following injection, but values at the end of the experiment were as low in this group as in the untreated controls.

It was unfortunate that all the animals in group 3, which received a small oral supplement of $500 \mathrm{mg}$. of copper, had higher initial blood-copper levels than those in the other two groups. In spite of this and the copper supplement, average blood-copper values for the group fell from 0.08 to $0.04 \mathrm{mg}$. $/ 100 \mathrm{ml}$. during the 4 months.

Blood-molybdenum figures for calves of all three groups were $0.06-0$. I I mg./1. These values were slightly higher than the range of $0.02-0.05 \mathrm{mg} .1$. found in cattle grazing pastures of normal molybdenum contents. Inorganic phosphorus and haemoglobin values were normal, ranging from $4^{.1}$ to $7.7 \mathrm{mg} . / 100 \mathrm{ml}$. and from 11.4 to $14.8 \mathrm{~g} . / 100 \mathrm{ml}$. respectively, and are not given in detail since there were no abnormal figures.

Tissues. Copper and molybdenum values of selected tissues from two control calves (nos. 2 and 3), one treated calf (no. 6) and one untreated cow (no. 9), which died during an attack of hypomagnesaemic tetany on farm $D$, are given in Table 4 .

Table 4. Copper and molybdenum contents of tissues from experimental animals on farms $D$ (Exp. I) and $O($ Exp. 2)

\begin{tabular}{|c|c|c|c|c|c|c|c|c|c|c|}
\hline \multirow[b]{2}{*}{ Reference } & \multicolumn{2}{|c|}{ Liver } & \multicolumn{2}{|c|}{ Spleen } & \multicolumn{2}{|c|}{ Heart } & \multicolumn{2}{|c|}{ Kidney cortex } & \multicolumn{2}{|c|}{ Blood } \\
\hline & $\begin{array}{l}\text { Copper } \\
\text { (p.p.m.) }\end{array}$ & $\begin{array}{l}\text { Molyb- } \\
\text { denum } \\
\text { (p.p.m.) }\end{array}$ & $\begin{array}{r}\text { Copper } \\
\text { (p.p.m.) }\end{array}$ & $\begin{array}{l}\text { Molyb- } \\
\text { denum } \\
\text { (p.p.m.) }\end{array}$ & $\begin{array}{r}\text { Copper } \\
\text { (p.p.m.) }\end{array}$ & $\begin{array}{l}\text { Molyb- } \\
\text { denum } \\
\text { (p.p.m.) }\end{array}$ & $\begin{array}{r}\text { Copper } \\
\text { (p.p.m.) }\end{array}$ & $\begin{array}{l}\text { Molyb- } \\
\text { denum } \\
\text { (p.p.m.) }\end{array}$ & $\begin{array}{l}\text { Copper } \\
\text { (mg./.) } \\
\text { 100 mil.) }\end{array}$ & $\begin{array}{l}\text { Molyb- } \\
\text { denum } \\
(\mathrm{mg} . / 1 .)\end{array}$ \\
\hline \multicolumn{11}{|l|}{ Farm D: } \\
\hline $\begin{array}{l}\text { Calf 2. Control* } \\
\text { Calf 3. Control } \\
\text { Calf 6. 5o mg. coppert } \\
\text { Cow 9. Control }\end{array}$ & $\begin{array}{l}4 \cdot 6 \\
4 \cdot 2 \\
5 \cdot 5 \\
6 \cdot 3\end{array}$ & $\begin{array}{l}3 \cdot 0 \\
2 \cdot 2 \\
3 \cdot 3 \\
3 \cdot 9\end{array}$ & $\begin{array}{l}4 \cdot 6 \\
3 \cdot 9 \\
6 \cdot 5 \\
-\end{array}$ & $\begin{array}{l}0.5 \\
0.7 \\
0.8 \\
\end{array}$ & $\begin{array}{r}8 \cdot 4 \\
10.0 \\
15.6 \\
-\end{array}$ & $\begin{array}{l}0.5 \\
0.5 \\
0.6 \\
\end{array}$ & $\begin{array}{l}18 \cdot 9 \\
16 \cdot 9 \\
20 \cdot 0 \\
-\end{array}$ & $\begin{array}{l}2 \cdot 4 \\
1 \cdot 4 \\
2 \cdot 3 \\
\end{array}$ & $\begin{array}{l}0.03 \\
0.02 \\
0.02 \\
-\end{array}$ & $\begin{array}{l}0.08 \\
0.09 \\
0.08 \\
-\end{array}$ \\
\hline \multicolumn{11}{|l|}{ Farm $O:$} \\
\hline $\begin{array}{l}\text { Calf 3. Control } \\
\text { Calf 5. Control } \\
\text { Calf 8. } 5 \text { g. copper } \\
\text { sulphate by mouth } \\
\text { each month for } \\
3 \text { months }\end{array}$ & $\begin{array}{r}5 \cdot 2 \\
6 \cdot 2 \\
18 \cdot 9\end{array}$ & $\begin{array}{l}2 \cdot 7 \\
3 \cdot 6 \\
4 \cdot 8\end{array}$ & $\begin{array}{r}6.9 \\
5 \cdot 0 \\
11 \cdot 8\end{array}$ & $\begin{array}{l}2 \cdot 2 \\
1 \cdot 1 \\
1 \cdot 7\end{array}$ & $\begin{array}{l}13.0 \\
11.0 \\
19.6\end{array}$ & $\begin{array}{l}0.8 \\
1.4 \\
0.7\end{array}$ & $\begin{array}{l}15.5 \\
13.4 \\
27.0\end{array}$ & $\begin{array}{l}2 \cdot 0 \\
2 \cdot 2 \\
4 \cdot 0\end{array}$ & $\begin{array}{l}0.03 \\
0.02 \\
0.08\end{array}$ & $\begin{array}{l}0.06 \\
0.06 \\
0.06\end{array}$ \\
\hline \multicolumn{11}{|l|}{ Farm S: } \\
\hline Calf I. Control & $7 \cdot 2$ & 3.4 & 6.5 & 17 & $11 \cdot 8$ & $1 \cdot 0$ & 19.5 & $3 \cdot 5$ & 0.03 & 0.06 \\
\hline
\end{tabular}

Liver-copper values for all three calves and the cow were very low. The single intravenous injection of $50 \mathrm{mg}$. copper to calf no. 6 appears to have made little difference to the amount of copper stored, although the figures were slightly higher than those for the two control calves nos. 2 and 3 . Tissue-molybdenum values were within the range found for animals grazing pastures of normal molybdenum content.

Clinical findings. Of the three untreated control calves, nos. 3 and 4 developed the typical pining syndrome, whereas the treated calves in both groups progressively improved in condition. It is of interest to note that the clinical condition of both treated groups was about equal, although copper values for blood and tissues were not increased to normal levels. Pl. I, 2 shows calf no. 6 (farm D) 4 months after one 
intravenous injection of $50 \mathrm{mg}$. copper. Comparison with Pl. I, I, which shows control calf no. 3 (same farm), indicates clearly the beneficial effect of copper therapy.

'The untreated calf no. 2, which showed no obvious clinical signs of the disorder, was a Shorthorn calf. Although it appeared normal clinically, copper values for blood and tissues were low (Tables 3 and 4 ).

\section{Exp. 2. Study of repeated larger doses}

This was devised to demonstrate the effects of repeated oral doses of copper sulphate.

Blood. Table 5 shows blood-copper values for four cows and calves given $5 \mathrm{~g}$. copper sulphate at monthly intervals for 3 months, and for a similar number of untreated control animals.

Table 5. Exp. 2. Effect of monthly dosing with copper sulphate on blood-copper values in cows and calves on farm $O$

\begin{tabular}{|c|c|c|c|c|c|c|c|c|}
\hline \multirow[b]{2}{*}{ Group } & \multirow[b]{2}{*}{ T'reatment } & \multirow[b]{2}{*}{ Animal } & \multicolumn{5}{|c|}{$\begin{array}{l}\text { Blood-copper values } \\
\text { (mg./100 ml.) }\end{array}$} & \multirow[b]{2}{*}{$\begin{array}{l}\text { Clinical } \\
\text { condition }\end{array}$} \\
\hline & & & No. & $\begin{array}{c}\text { Before } \\
\text { treatment }\end{array}$ & $\begin{array}{l}\text { After } \\
\text { I month }\end{array}$ & $\begin{array}{l}\text { After } \\
2 \text { months }\end{array}$ & $\begin{array}{c}\text { After } \\
3 \text { months }\end{array}$ & \\
\hline \multirow[t]{10}{*}{ A (control) } & No copper & Calf & $I$ & 0.08 & 0.05 & 0.02 & 0.04 & Poor \\
\hline & & Calf & 2 & 0.06 & 0.03 & 0.04 & 0.04 & \\
\hline & & Calf & 3 & 0.03 & 0.02 & 0.04 & 0.03 & \\
\hline & & Calf & 5 & 0.03 & 0.04 & 0.02 & 0.02 & \\
\hline & & & Mean & 0.050 & 0.035 & 0.030 & 0.032 & \\
\hline & & Cow & I & 0.05 & 0.06 & 0.06 & 0.05 & \\
\hline & & Cow & 2 & 0.05 & 0.06 & 0.04 & 0.04 & \\
\hline & & Cow & 3 & 0.04 & 0.05 & 0.04 & 0.04 & \\
\hline & & Cow & 5 & 0.03 & 0.04 & 0.03 & 0.04 & \\
\hline & & & Mean & 0.042 & 0.048 & 0.042 & 0.042 & \\
\hline \multirow[t]{10}{*}{ B (treated) } & 5 g. copper & Calf & 4 & 0.06 & 0.07 & 0.08 & 0.08 & Good \\
\hline & sulphate by & Calf & 6 & 0.03 & 0.08 & 0.07 & 0.08 & \\
\hline & mouth at & Calf & 7 & 0.08 & 0.07 & 0.08 & 0.07 & \\
\hline & monthly & Calf & 8 & 0.03 & 0.07 & 0.06 & 0.08 & \\
\hline & intervals & & Mean & 0.050 & 0.072 & 0.070 & 0.078 & \\
\hline & & Cow & 4 & 0.03 & 0.07 & 0.06 & 0.07 & \\
\hline & & Cow & 6 & 0.03 & 0.06 & 0.08 & 0.07 & \\
\hline & & Cow & 7 & 0.03 & 0.05 & 0.05 & 0.06 & \\
\hline & & Cow & 8 & 0.05 & 0.07 & - & 0.08 & \\
\hline & & & Mean & 0.035 & 0.058 & 0.063 & 0.07 & \\
\hline
\end{tabular}

It is apparent that these larger repeated doses of copper increased blood-copper levels. Mean values for the four treated calves in group B increased from 0.050 to $0.078 \mathrm{mg} .1$ joo $\mathrm{ml}$. and those for the four cows from 0.035 to $0.07 \mathrm{mg} . / 100 \mathrm{ml}$. during the 3 months.

Values for the untreated control calves in group A fell from an already low average of 0.05 to a lower one of $0.032 \mathrm{mg} . / 100 \mathrm{ml}$, , but mean values for the control cows remained unaltered at the low level of $0.042 \mathrm{mg}$./ $100 \mathrm{ml}$. throughout the experimental period.

Blood-molybdenum values for the experimental animals on this farm $(O)$ were slightly lower than those for animals on farm $\mathrm{D}$ and averaged $0.06 \mathrm{mg} . / \mathrm{l}$, the range being $0.04-0.08 \mathrm{mg}$. $/ \mathrm{l}$. Values for inorganic phosphorus and haemoglobin for both cows and calves were normal. 
Tissues. Copper and molybdenum values for selected tissues from two control calves (nos. 3 and 5 ) and one treated calf (no. 8) from farm $\mathrm{O}$ are given in Table 4. Similar values are given for tissues from an untreated 'pining' calf from a neighbouring farm, $\mathrm{S}$.

All the tissues from calf no. 8 showed a higher copper content than those from the two controls. This indicates that the larger supplement of copper resulted in some degree of storage in the tissues, especially in the liver, where the copper content of i 8.9 p.p.m. in D.M. was about three times as great as that for the livers of the two control calves.

The copper values of tissues from an untreated calf (no. $r$ ) on farm $\mathrm{S}$ indicate again the low copper status of 'pining' calves.

Molybdenum values indicate that little molybdenum was stored in any of the tissues examined, but of these the highest concentrations were found in liver and in kidney cortex. It is noteworthy that livers from calves grazing fields 8 and 9 on farm D with respective pasture molybdenum values of 19.5 and 16.1 p.p.m. in D.M. did not have a higher molybdenum content than livers from calves grazing fields ro and $\mathrm{I}$ i on farm $\mathrm{O}$, where the molybdenum content was only about 4 P.p.m. in D.M.

These liver-molybdenum values are very similar to those of 2-5 p.p.m. in D.M. reported by Dick \& Bull (I945) for cattle that had received large amounts of molybdenum over a period of 3 years.

Clinical findings. The four untreated calves in group A progressively deteriorated in condition during the experiment. Among them were both cross-bred and pure West Highland. The first clinical sign of the disease was again the stilted gait; the hair on the ears and face turned from a dark reddish-brown colour to a light dun colour. General growth was retarded, and the apparent fineness of the limb bones was again a distinct feature. The calves that received monthly supplements of copper developed normally and there was no discoloration of the coat.

\section{Pathological observations}

Haematological examinations were made throughout the experiment because of the occurrence of anaemia in certain copper-deficiency conditions reported from other parts of the world.

No evidence of anaemia in any of the experimental calves was observed (Table 6).

Table 6. Comparison of haematological data from Caithness and Western Australia

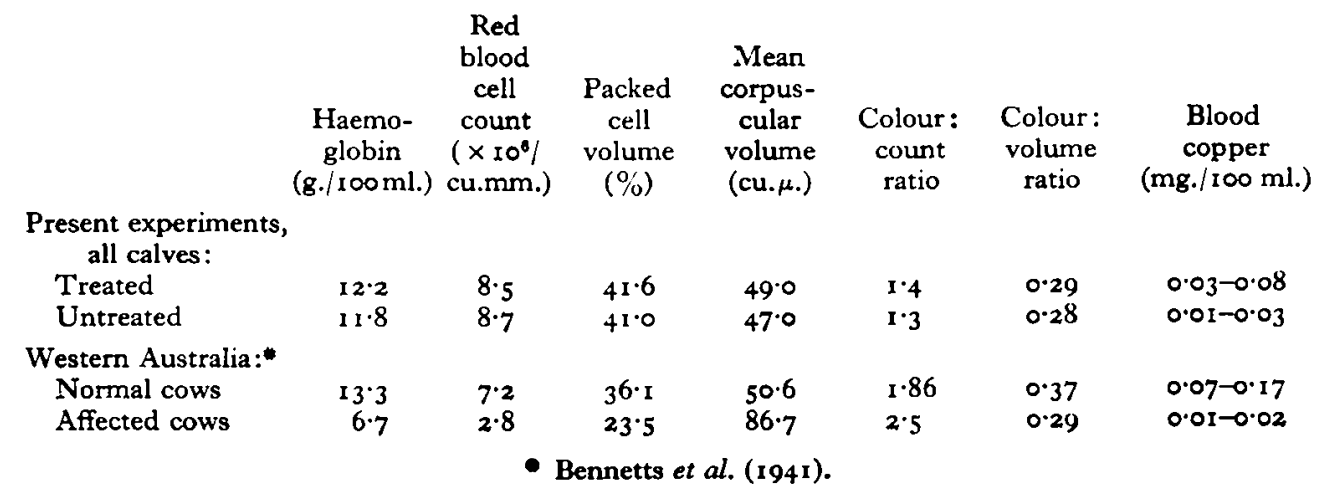


No gross pathological changes were observed in the organs of the untreated control calves, with the exception of the kidneys of calf no. 3 from Farm D and of calf no. 5 from farm $O$. In these animals both kidneys showed numerous minute, pale, circumscribed areas in the cortex. The amount of renal and pelvic fat in the control calves was very small and the fat had a distinctive yellow colour.

No exostoses were observed in the skeletal system and there were no lesions in, or associated with, the metacarpal or metatarsal joints that might have accounted for the symptoms of stiffness during life. The metatarsal bones of treated and untreated calves were similar in size, and the apparent fineness of the legs of untreated calves appears to be due to poor development of muscle rather than to diminution in bone formation. 'l'he only other difference observed was in the consistency of the ruminal contents of treated and control calves. That of the controls was dry and rough with little fluid present, but that of the two treated animals was of normal fluid consistency.

\section{Histological examinations}

No haemosiderin deposition was demonstrated in liver, spleen, kidney or heart tissue from either treated or control calves.

Liver. Sections of livers of control calves and of the calf from farm S, stained with Scharlach $\mathrm{R}$, showed fatty degeneration distributed mostly at the periphery of the lobule and around the bile ducts (Pl. 2, I).

In addition, in sections stained with haematoxylin and eosin, there was an obvious lack of eosinophil staining of the hepatic cells around the central vein. The ability to take up the eosin stain progressively increased towards the periphery of the lobule. Viewed under the oil-immersion objective the cytoplasm of these cells presented an irregular globular granularity, the nature of which has not been determined. No nuclear changes were observed. Histologically, there was no difference in the glycogen content of livers from treated and untreated calves. Because of the different coppermolybdenum relationships of the experimental pastures on farms $\mathrm{D}, \mathrm{O}$ and $\mathrm{S}$, it should be emphasized at this stage that these changes were present in all the control animals slaughtered from all three farms.

In the calves that had received copper supplements fatty degeneration was not demonstrated. There was, however, to a lesser degree, an absence of eosin reaction in the cells around the central vein of the lobule and similar granulation of the cytoplasm.

Kidneys. The only cellular changes observed were the degenerative changes of cloudy swelling in the kidneys of all the control calves. In calves nos. 3 and 5 from farm $\mathrm{O}$ there were areas of large monocytes grouped around blood vessels ( $\mathrm{Pl} .2,2)$. This perivascular monocytosis was irregular in distribution, and examination of serial sections failed to reveal any obvious pattern.

\section{Examination of faeces}

The low incidence of helminth infestation in cattle in Caithness and the high incidence of liver-fluke infestation has been reported by Jamieson (1948-9). Although the possibility of liver-fluke infestation was extremely remote in such young animals, examination for the presence of liver-fluke eggs was carried out, with negative results. 
In the experimental period ten samples of faeces were examined from each animal. 'T hhroughout the experiment calf no. 6 in Exp. 2 gave a count of $100 \mathrm{eggs} / \mathrm{g}$. faeces on two occasions, the remainder of the calves yielded negative worm-egg counts. None of the adult cattle yielded a worm-egg count above $200 \mathrm{eggs} / \mathrm{g}$. faeces.

\section{Observations on distribution and incidence of the disorder}

Blood-copper survey. Results obtained from blood samples taken from 222 cows and 509 calves and stirks distributed on 123 farms in Caithness are shown as a distribution chart in Fig. 1 . This indicates that $63.7 \%$ of the values for cows, stirks and calves are below $0.07 \mathrm{mg} . / 100 \mathrm{ml}$. and can be regarded as low. Only $26.7 \%$ of the values for calves and $19.8 \%$ of those for cows are above $0.07 \mathrm{mg} . / 100 \mathrm{ml}$.

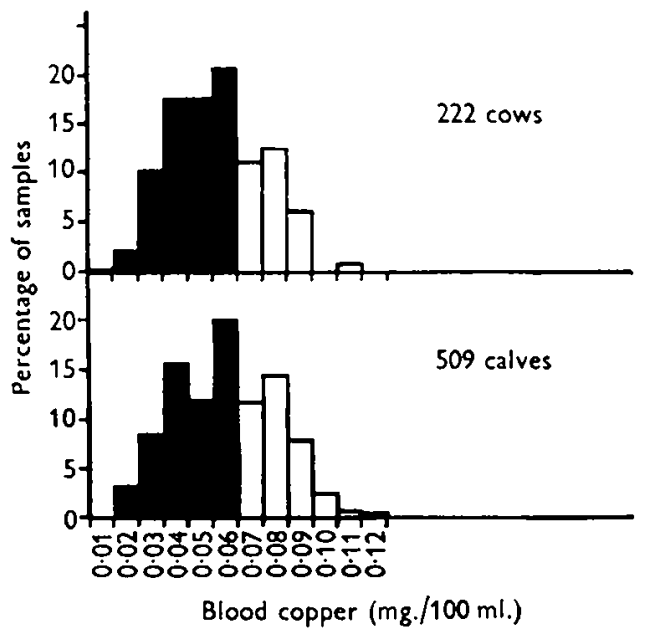

Fig. I. Distribution of blood-copper values among cows and calves on 123 farms in Caithness, 1948-9; values of $0.07 \mathrm{mg}$./100 ml. and above are unshaded.

Correlation of these results with the soil types of Caithness shows that the incidence of the disorder is highest around the marginal peaty areas in the Halkirk area, although isolated affected farms are found in the sandy coastal machairs particularly in the John O'Groats-Lybster seaboard.

Liver-copper survey. The distribution of copper values obtained from forty-five samples of liver from adult bovines from two slaughter-houses in Caithness are given in Fig. 2. Thirty, or two-thirds of the values, are below 20 p.p.m. in D.M. and can be regarded as indicating a low copper status of the animal. Of the remaining fifteen, twelve are below 60 p.p.m., and only three fall within the average values of $67-$ 200 p.p.m. reported by Cunningham (1946) for normal yearling and adult cattle.

For comparison, the distribution of copper values for forty-two samples of bovine livers obtained from slaughter-houses in Aberdeenshire is given in Fig. 3. Here only eleven out of forty-two, or about one-quarter, are below 20 p.p.m. in D.M., whereas eighteen, or nearly one-half, are above 60 p.p.m.

The origins of the eleven samples that showed copper values below 20 p.p.m. were 
traced, and it is interesting that all came from farms where symptoms indicating hypocupraemic conditions in the animals were observed. These are being investigated more fully.

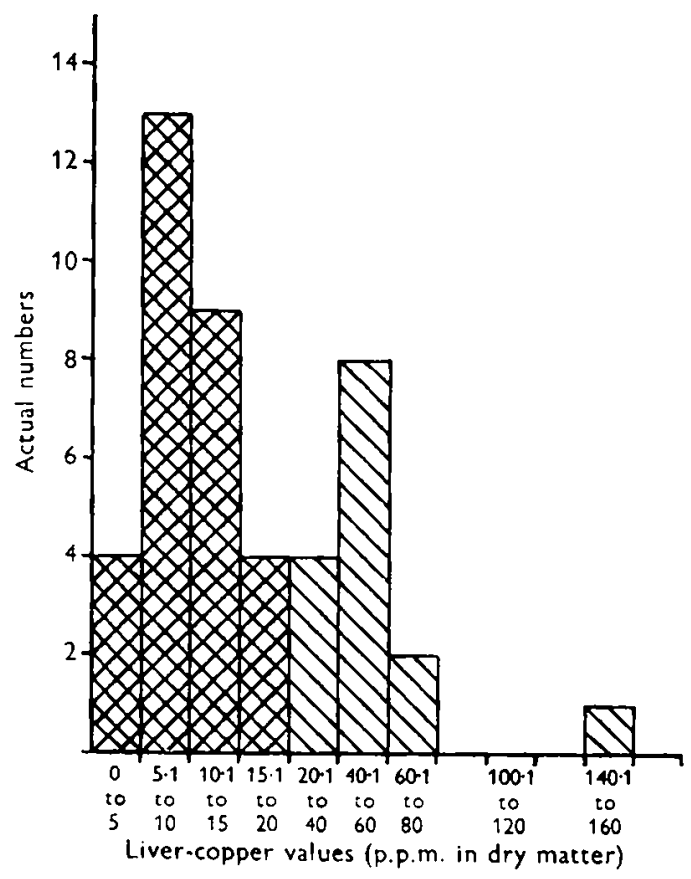

Fig. 2. Distribution of copper values in forty-five random samples of bovine liver from slaughter-houses in Caithness, 1948; values of 20 p.p.m. and above are shaded with single diagonal lines.

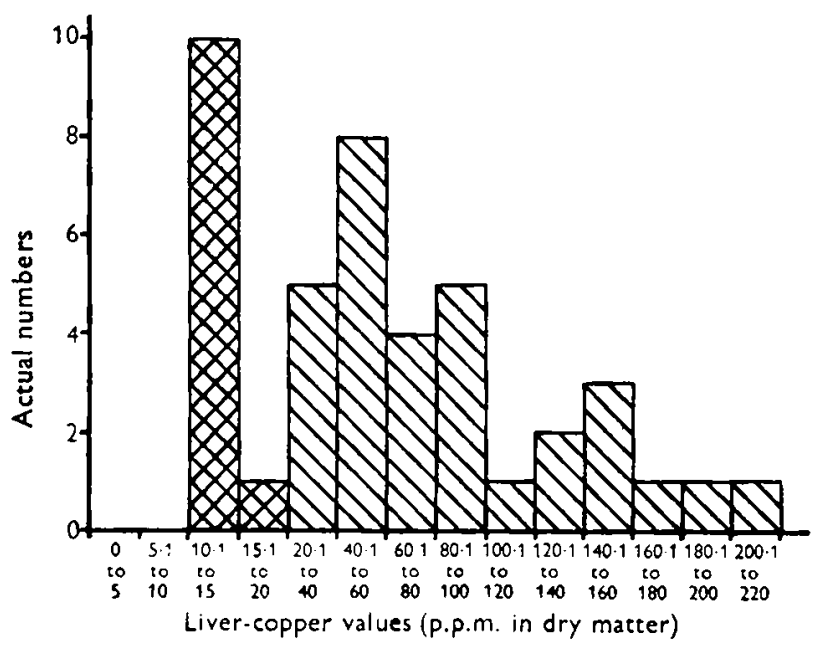

Fig. 3. Distribution of copper values in forty-two random samples of bovine liver from slaughter-houses in Aberdeenshire, 1948; values of 20 p.p.m. and above are shaded with single diagonal lines. 


\section{DISCUSSION}

'These investigations clearly indicate that the pining syndrome in calves in Caithness is due to a deficiency of copper in the animal. The response to such a small amount of copper as $50 \mathrm{mg}$. intravenously, or $500 \mathrm{mg}$. orally, was remarkable. This small dose was apparently sufficient to allow the calves to develop normally and to prevent the appearance of the pining syndrome, although it was not enough to allow blood and tissue values to attain the generally accepted normal limits.

Some aspects of the condition resemble those of 'falling disease' in Western Australia described by Bennetts \& Hall (1939), Bennetts et al. (194I) and Bennetts, Beck \& Harley (1948), and some those of 'peat scours' described by Cunningham (1946); certain features are quite distinct, and no parallel has been found so far in the literature. The distinctive features are: (1) only young stock appear to be clinically affected, (2) absence of anaemia and pica, (3) absence of skeletal lesions that might account for the stilted gait of affected calves, (4) absence of deposition of haemosiderin in any tissues of pining calves so far examined, (5) an apparently adequate copper content of the pastures on which 'pining' occurs. In 'falling disease', adult as well as young stock were affected, and, indeed, it was in the adult dairy cows that the condition was most severe. In Caithness the adult animals appeared to be unaffected, but when they were the condition was subclinical, and was certainly not of the acute type seen in the calves. Whether copper supplements would improve the condition of adult cattle in Caithness is worth investigating and, indeed, several feeding trials are already being carried out. Again, in the 'falling disease' syndrome, seasonal anaemia and depraved appetite were reported, but at no time were these two symptoms observed in Caithness. Although calves in 'falling disease' areas showed a stilted gait, and in this respect resembled the pining calves in Caithness, Bennetts (1942) reported that this was associated with osseous outgrowths in the metatarsal regions. Such osseous outgrowths were not observed in calves in Caithness.

The absence of haemosiderin is another difference, but it is difficult to say at this stage whether this is significant, since Bennetts has not reported pathological findings for such young animals, and the tissues of the Caithness calves which showed no haemosiderosis were obtained before the terminal stages of the pining condition. It was of interest, however, that the cow which died from hypomagnesaemia on farm D showed extensive haemosiderosis in the liver, spleen and kidneys.

The most distinctive difference between hypocupraemic conditions reported in Australasia and in Great Britain is that in the former the pastures have either very low or marginal copper contents, but in the latter they have an apparently adequate copper content. No real deficiency of copper in pastures has so far been confirmed in Great Britain.

Comparison with the copper-deficiency syndrome in beef cattle, which occurs on peat land in New Zealand, again shows certain differences between the two conditions. Cunningham (1946) states that some calves die at, or soon after, birth and a few develop symptoms of ataxia similar to those found in ataxic lambs. These findings have not been observed in Caithness, and if death does occur it is usually during the 


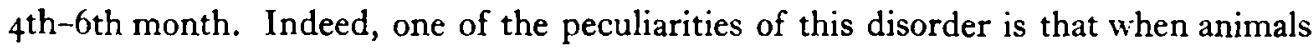
survive the critical 3-6 months' period they improve during the winter, when they are housed and fed on winter rations, although their condition always remains suboptimal.

It may be that change from pasture to stall-feeding allows sufficient storage of copper to make possible more normal development since it was shown by Allcroft \& Parker (1949) that transference of hypocupraemic animals from grass to winter feeding resulted in an elevation of blood-copper values. Deaths in yearling stock in copperdeficient dairy herds on peat land in New Zealand reported by Cunningham (1946) may be due to the fact that these animals are at pasture all the year round. It is of interest to note that Cunningham also reports a breed susceptibility to peat scours; he found Jerseys more likely to succumb to its effects than Shorthorns or Friesians, but he does not state whether some breeds of beef cattle are more susceptible than others, as is found to be the case in Caithness. He does indicate, however, that adult cattle as well as young stock are affected in both dairy and beef herds.

Again the syndrome seen in Caithness differs from the hypocupraemic condition of dairy cows on peat land in Shropshire described by Allcroft \& Parker (1949). In Shropshire adult cattle and stock from yearling stage onwards are chiefly affected. It is noteworthy also that blood-copper levels of the calves on peat land in Shropshire remained within normal limits until yearling stage. The different methods of husbandry in beef herds in Caithness and in dairy herds in Shropshire may in part account for the different clinical conditions observed in the two peat areas. In dairy herds in Shropshire, calves are taken away from their mothers $\mathrm{I}-2$ days after birth, and are raised on proprietary calf foods which supply a normal amount of copper. Analysis of various samples of calf foods used on the Shropshire farm showed a copper content of I0-13.8 p.p.m. Added to this the calves are kept inside for several months without being allowed out to graze and are not put on peaty pastures until they are about I year old.

In contrast to this management, the calves in Caithness remain with their mothers for 6-8 months, are depastured soon after birth and have ample opportunity for grazing on peat land, and are never given any proprietary foods which might supply adequate available copper. From the limited amount of data obtained it is evident that the mothers of these calves have a low copper status, so that the calves must be born with inadequate copper reserves, and since the cows' milk would be low in copper (Beck, I94I) and the pastures on the peat land would not supply sufficient available copper, they would have no chance of making good this deficiency.

Dick \& Bull (1945) and Cunningham (1946) have suggested that an increased molybdenum content of pastures reduces storage of liver copper in ruminants. Since fields 8 and 9 on farm $\mathrm{D}$, where the pining syndrome occurred in the experimental calves, have fairly high molybdenum contents of 19.5 and $16 \cdot \mathrm{I}$ p.p.m. in D.M. respectively, it might be argued that this was the cause of the low copper status of the animals. It should be pointed out, however, that the condition occurred equally on fields IO and I I on farm $\mathrm{O}$ where molybdenum values were 4.3 and 3.8 p.p.m. respectively, and on field I7 on farm S, where the molybdenum figure was 7.7 p.p.m. in D.M. The identical 
clinical syndrome occurs therefore on pastures of widely different molybdenum contents, and the evidence at this stage does not seem to indicate that excess molybdenum in pastures of normal copper content is the factor which causes the low copper status of the cattle.

It is of interest, however, that yearling calves at grass on a teart pasture in Somerset had low blood-copper values, the mean for twelve animals being $0.04 \mathrm{mg}$. $/ 100 \mathrm{ml}$., although there was no clinical pining and the animals appeared to be in excellent condition. It has also been found that young stock outside the teart area in Somerset on pastures of normal copper and molybdenum content have equally low blood-copper values (Allcroft, 1949) without exhibiting any signs of unthriftiness.

Discussion of the histological findings in the pining calves is necessarily limited to general observations since, with the exception of that of Bennetts and his co-workers, no histological information on similar disorders is available, and therefore at this stage the significance of the hepatic changes can only be speculative. It should be noted, however, that granulation of the liver cells in cattle that died of 'falling disease' was described by Bennetts \& Hall (1939). At the present moment, therefore, dysfunction of copper metabolism would appear to be another factor which can be added to the already long list of those associated with hepatic fatty changes. From the experimental data presented it seems reasonable to conclude that even such a small dose of copper as $50 \mathrm{mg}$. given intravenously will prevent the fatty changes and reduce the granular condition. The glomerular changes described by Bennetts in 'falling disease' were not observed in these few experimental calves. It is well known that localized infiltrative processes are common in a wide variety of conditions, so that the question of whether the lesion observed in the kidney cortex is of significance or not must await further observations.

It is clear, however, from these preliminary data that on peat areas in Caithness a cachectic condition occurs in calves of certain beef breeds which is associated with a very low copper status of the animal and can be cured and prevented by very small amounts of copper. It is not associated with a low copper content of the pastures, although some pastures on which the condition occurs come into the 'moderately low' category of peat pastures in New Zealand, reported by Cunningham (r946).

Much more extensive observations are necessary before all the details of the aetiology of the disorder can be clarified. At present large-scale feeding trials are in progress, and different methods of supplying additional copper are being tried to get information on the most economical way of supplying this essential trace element to cattle kept under semi-range conditions.

\section{SUMMARY}

I. A pining condition is described which occurred in calves of the Aberdeen-Angus breed and cross-bred West Highland strains when at pasture in certain areas of Caithness. The disorder was characterized by a stilted gait, discoloration and sometimes depigmentation of the hair and progressive cachexia resulting in death in severe cases.

2. The copper status of these calves was very low, as shown by blood-copper values of $0.01-0.04 \mathrm{mg}$. $/ 100 \mathrm{ml}$. and by liver-copper values of $4 \cdot 2-7 \cdot 2$ p.p.m. in D.M. The 
copper contents of spleen, heart, and kidney cortex tissues were also lower than those from non-pining calves given copper sulphate.

3. Pasture samples from fields on four farms on which the disorder occurred had copper values from 4.8 to 20.8 p.p.m. in D.M. and molybdenum values from 3.8 to 19.5 P.p.m. in D.M. The condition occurred as often on pastures containing $I \cdot I$ and 4.3 p.p.m. molybdenum as on pastures containing I 6 and I9. 5 p.p.m. It would appear therefore that a high molybdenum intake is not the chief factor in limiting absorption or storage of copper in the animals.

4. Small supplements of copper as copper sulphate cured and prevented the disorder. It was found that as little as $50 \mathrm{mg}$. copper intravenously, or $500 \mathrm{mg}$. by mouth, given once was sufficient for normal development but was not sufficient to increase blood-or tissue-copper values to normal limits. Administration of three $5 \mathrm{~g}$. doses of copper sulphate at monthly intervals increased blood-copper values to a mean of $0.078 \mathrm{mg} . / 100 \mathrm{ml}$. for four calves, compared with a mean of $0.032 \mathrm{mg} . / 100 \mathrm{ml}$. for four untreated calves. Copper values for liver, spleen, heart and kidney from a similarly treated calf were higher. The copper content of the liver was i 8.9 p.p.m., compared with 5.2 and 6.2 p.p.m. in D.M. for two untreated control calves.

5. The molybdenum values of blood of nine cows and nine calves on pastures with molybdenum contents of 16.1 and 19.5 P.p.m. in D.M. were slightly higher than for eight cows and eight calves on pastures with molybdenum contents of 3.8 and 4.3 p.p.m. in D.M. There was no evidence, however, of increased molybdenum content of tissues from calves on the higher-molybdenum pastures compared with those from calves on the pastures with lower molybdenum content.

6. Other blood constituents such as inorganic phosphorus, calcium, magnesium and haemoglobin were within normal limits in pining calves.

7. Seven calves were killed for post-mortem examination. Fatty degeneration of the liver was found in the five that received no copper but not in the two given copper therapy. An unclassified globular granulation of the liver cells was noted in untreated calves, and to a lesser extent in treated calves. In the kidneys of untreated calves cloudy swelling was observed and in two of these animals renal perivascular monocytosis was present. No evidence of anaemia was noted in either treated or untreated animals.

8. Seven hundred and twenty-one blood samples taken from cattle of various ages on 123 farms in Caithness showed that $63.7 \%$ of the blood-copper values for both calves and cows were low, or were less than $0.07 \mathrm{mg} . / 100 \mathrm{ml}$. Haemoglobin values were within the normal range.

9. Two-thirds of forty-five random liver samples from cattle sent to slaughterhouses in Caithness had copper values of less than 20 p.p.m. on a dry-matter basis, indicating a low copper status of the animals. Of forty-two samples of bovine liver from slaughter-houses in Aberdeenshire, only one-quarter contained less than 20 p.p.m. in D.M. Investigation of farms from which these samples came showed in animals from 6 months to I year old a condition clinically similar to the pining symptoms seen in Caithness.

I0. From these observations it is concluded that the condition of pine in calves in 

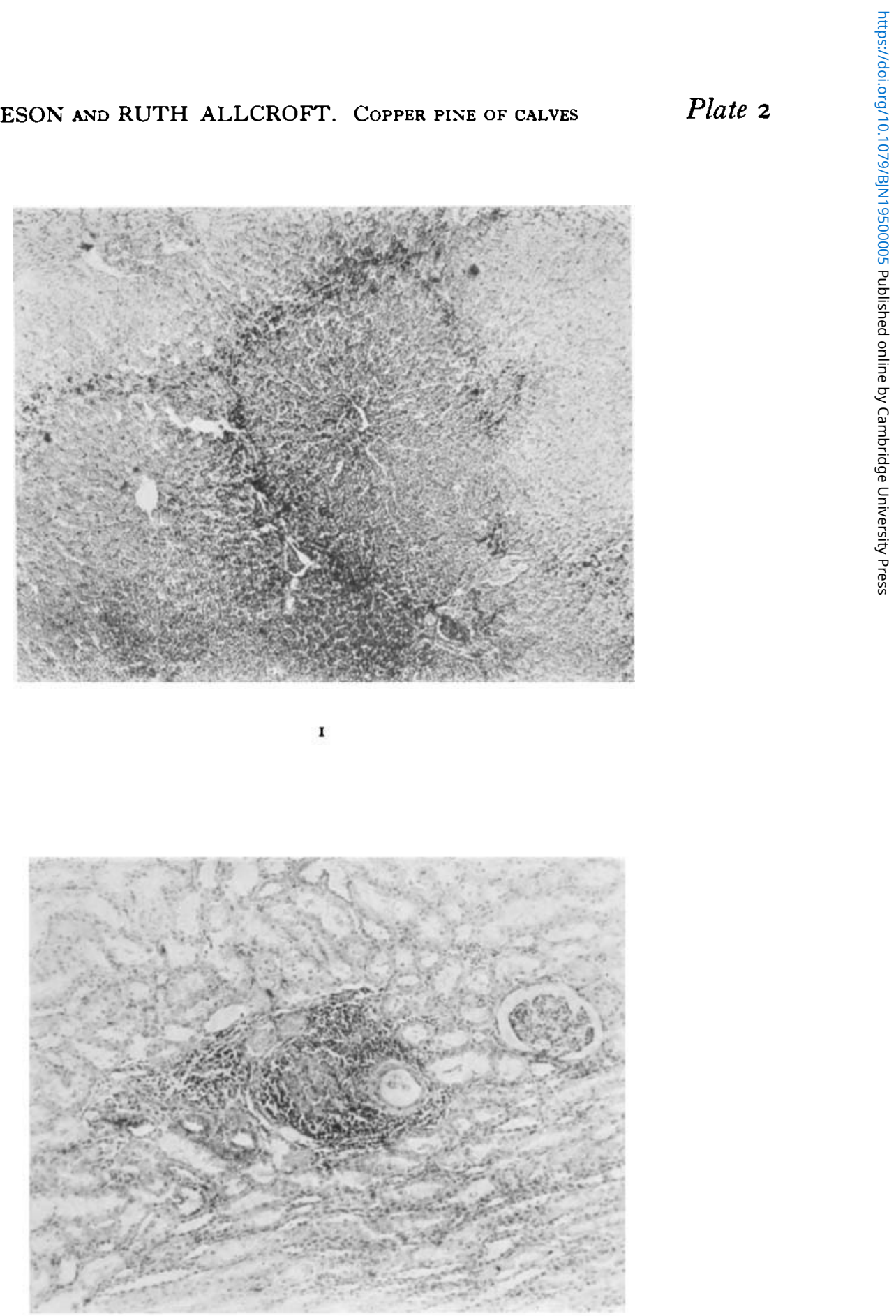

2

British Fournal of Nutrition, Vol. 4 , No. I 

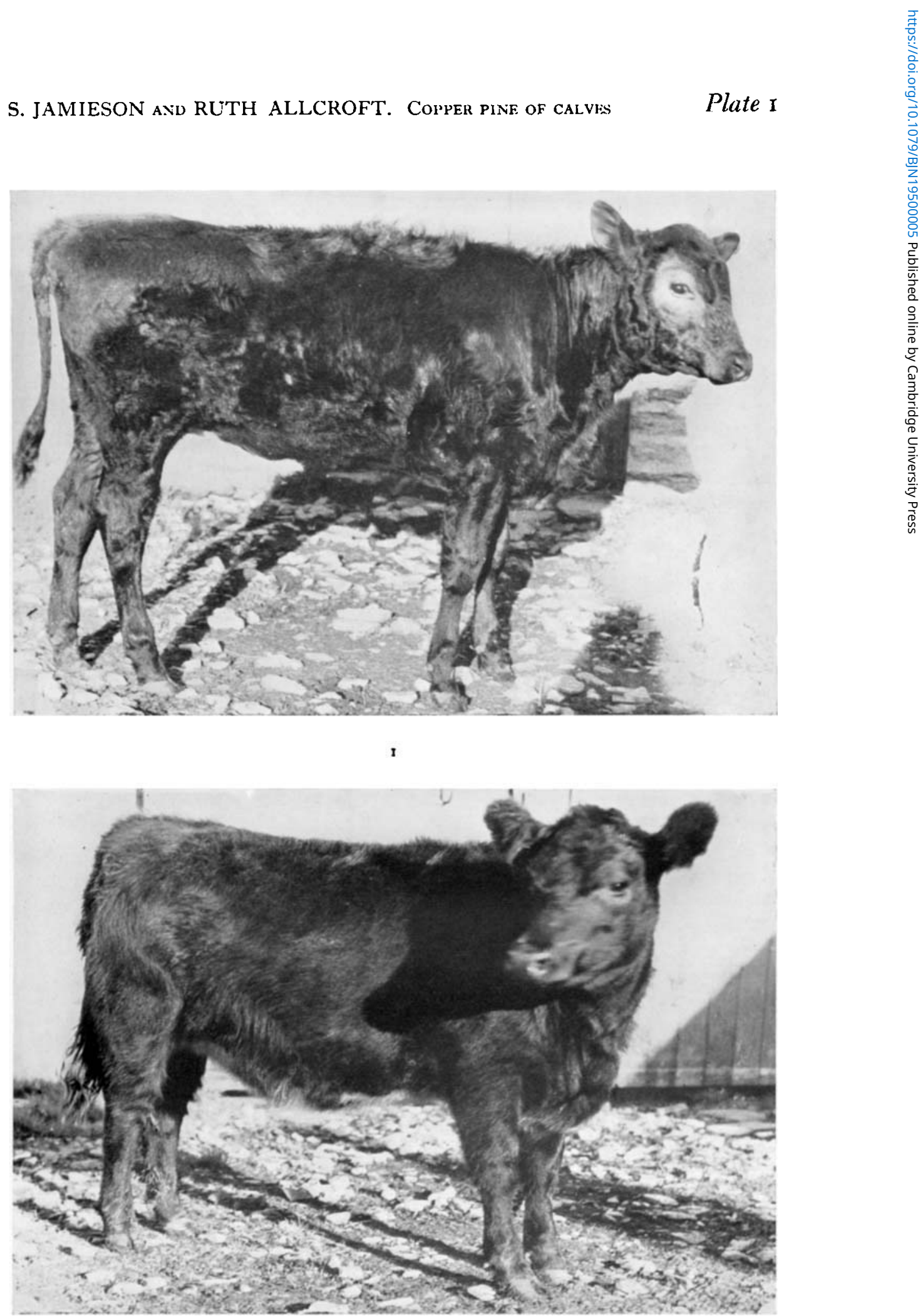

British Yournal of Nutrition, Vol. 4, No. I 
Caithness is due to a low copper status of the animals and can be cured, or prevented, by small supplements of copper. This low copper status in the animal is not due to a deficiency of copper per se in the pastures, and it is suggested that there is some factor present or absent in the pastures which seriously interferes with the metabolism of copper in calves, particularly of certain beef breeds, at a critical time in their development from 2 to 6 months of age.

We wish to thank Mr L. G. Donald for his help in the field work.

\section{REFERENCES}

Allcroft. R. (1949). In preparation.

Allcroft, R. \& Parker, W. H. (1949). Brit. Y. Nutrit. 3, 205.

Beck, A. B. (1941). F. Dep. Agric. W. Aust. 18, 285.

Bennetts, H. W. (1942). भ. Dep. Agric. W. Aust. 19, 96.

Bennetts, H. W., Beck, A. B. \& Harley, R. (1948). Aust. vet. J. 24, 237.

Bennetts, H. W., Beck, A. B., Harley, R. \& Evans, S. T. (194I). Aust. vet. J. 17, 85.

Bennetts, H. W. \& Hall, H. T. B. (1939). Aust. vet. J. 15, 152.

Clark, E. P. \& Collip, J. B. (1925). \%. biol. Chem. 63, $46 \mathrm{r}$.

Clayden, E. C. (1948). Practical Section Cutting and Staining. London: J. A. Churchill.

Cunningham, I. J. (1946). N.Z. Y. Sci. Tech. 27, sect. A, p. 38 r.

Denis, W. (1922). Y. biol. Chem. 52, 411 .

Dick, A. T. \& Bull, L. B. (1945). Aust. vet. F. 21, 70.

Eden, A. (1944). J. comp. Pathol. 54, 220.

Eden, A. \& Green, H. H. (1940). Biochem. F. 34, 1202.

Ferguson, W. S., Lewis, A. H. \& Watson, S. J. (1943). \%. agric. Sci. 33, 44.

Fiske, C. H. \& Subbarow, Y. (1925). \%. biol. Chem. 66, 375.

Gordon, H. McL. \& Whitlock, H. V. (1939). \%. Coun. sci. industr. Res. Aust. 12, 50.

Holman, H. H. (1944). In Diagnostic Methods in Veterinary Medicine, by G. F. Boddie. Edinburgh: Oliver and Boyd.

Jamieson, S. (1948-9). Scot. Agric. 28, 155.

Kramer, B. \& Tisdall, F. F. (1921). F. biol. Chem. 47, 475.

Newcomer, H. S. (1923). J. biol. Chem. 55, 569.

Perrin, D. D. (r946). N.Z. Y. Sci. Tech. 27, sect. A, p. 396.

Vallance-Owen, J. (1948). F. Path. Bact. 60, 325 .

\section{EXPLANATION OF PLATES}

\section{Plate I}

I. Calf no. 3 (farm D) of the Aberdeen-Angus breed, showing pining and depigmentation of the hair around the eyes. Live weight $336 \mathrm{lb}$. Dead weight $\times 89 \mathrm{lb}$.

2. Calf no. 6 (farm D) 4 months after receiving one intravenous injection of $50 \mathrm{mg}$. copper. This animal lived under the same conditions as calf no. 3. Live weight $448 \mathrm{lb}$. Dead weight $264 \mathrm{lb}$.

\section{Plate 2}

I. Liver of calf no. 3 (farm D). Shows the peripheral distribution of fatty changes in the lobule. Scharlach R. $\times 50$.

2. Kidney of calf no. 3 (farm D). Area of monocytic infiltration. Haematoxylin and eosin. $\times 90$. 